\title{
JCNaR
}

\section{Synthesis of 2-(4-Allyl-2-Methoxy Phenoxy)-N,N-Bis(2- Hydroxyethyl) Acetamide from the Transformation of Eugenol Isolated from Clove Oil}

\author{
Mimpin Ginting $^{1 *}$, Darwis Surbakti ${ }^{1}$, Novi Triana ${ }^{1}$ \\ 1* Department of Chemistry, Faculty of Mathematics and Natural Science, Universitas Sumatera Utara.
}

\begin{abstract}
Eugenol as the main component of clove oil has been isolated through $\mathrm{NaOH}$ salting procedure followed by $\mathrm{H}_{2} \mathrm{SO}_{4}$ hydrolysis, n-hexane partitioning and purification with vacuum distillation. $71 \%(\mathrm{v} / \mathrm{v})$ eugenol was produced used gas chromatography analysis(purity : 97.70\%). 2-(4-allyl-2-methoxy phenoxy)-N,N-bis(2-hydroxyethyl) acetamide compound has the potential as antibacterial or substances for medicine in pharmaceutical can be synthesized from eugenol isolated through alkoxylation, esterification and followed by amidase. Alkoxylation was done using Williamson method through $\mathrm{NaOH}$ transformation of hydroxyl functional group in eugenol to form sodium eugenolate then with $\alpha$-monochloroacetate substitution in reflux condition, eugenyl acetate was produced. The acid produced was extracted with ether $/ \mathrm{Na}_{2} \mathrm{CO}_{3}$, followed by recrystallization using hot water and produced $70.52 \%$ solid form. Eugenyl acetate esterification with methanol in benzene solvent with $\mathrm{H}_{2} \mathrm{SO}_{4}$ catalyst in reflux condition produced methyl eugenol acetate liquid with $81.36 \%$ of yield. Amidase of methyl eugenol acetate with diethanolamine and sodium methoxide catalyst with methanol solvent in reflux condition. After purification, 2-(4-allyl-2-methoxy phenoxy)-N,N-bis(2-hydroxyethyl) acetamide compound in solid form is produced with $72.99 \%$ yield. Eugenol isolated, eugenyl acetate and methyl eugenol acetate had their structures analyzed with FT-IR spectroscopy while 2-(4-allyl-2-methoxy phenoxy)-N,N-bis(2-hydroxyethyl) acetamide compound was analysed using FT-IR and ${ }^{1} \mathrm{H}-\mathrm{NMR}$.
\end{abstract}

Keyword:Eugenol, etherification, eugenyl acetate, esterification, methyl eugenol acetate, amidase, 2-(4-allyl-2-methoxy phenoxy)-N,N-bis(2-hydroxyethyl) acetamide.

Received November 1, 2018| Revised December 20, 2018 | Accepted January 24, 2019

\section{Introduction}

Clove oil is an essential oil from cloves plant (Syzygium aromaticum) in the family Myrtaceae which is planted a lot in Indonesia, India and Madagascar (Alma, et, al, 2007). Eugenol is the main component to determine the quality of clove oil, in which the content reaches $70-96 \%$

\footnotetext{
*Corresponding author at:Department of Chemistry, Faculty of Mathematics and Natural Science, Universitas Sumatera Utara
}

E-mail address: mimpin.ginting@yahoo.com 
(Kardiman, 2005). The higher eugenol compound in the clove oil, the higher its quality and value. SNI 06-2387-2006 standard is a minimum of 78\% eugenol in clove oil (BSN, 2006).

Eugenol is a phenolic compound with molecular formula of $\mathrm{C}_{10} \mathrm{H}_{12} \mathrm{O}_{2}$. It contains a number of functional groups such as allyl $\left(-\mathrm{CH}_{2}-\mathrm{CH}=\mathrm{CH}_{2}\right)$, phenol $(-\mathrm{OH})$ and methoxy $\left(-\mathrm{OCH}_{3}\right)$ which allow eugenol as the base material to synthesize other compounds as eugenol derivatives with various activities and potentially more valuable (Anwar, 1994). Eugenol and the derivatives have strategic roles in various industries like pharmaceutical, cosmetics, food and drinks, cigarette, pesticides, fishery, mining, active packaging and any other chemical industries (Pramod,et al, 2010). Therefore eugenol from clove oil can be used as the raw material for pesticides, also several studies that this compound and the derivatives are effective to control nematode, pathogenic fungi, bacteria, insects as pests or as medicine in pharmacology (Wiratno, 2009).

Eugenol and its derivatives have strategic roles in many industries has led to a big market opportunity that supported by the abundance of clove oil in Indonesia, therefore eugenol isolation and the synthesis of the derivatives need to be developed. With the expansion of agroindustry for eugenol processing and followed by its derivatives, it is expected that Indonesia does not only cover its own industrial needs but also able to become the main supplier for world's needs for eugenol and the derivatives compound. Several studies with eugenol have been done, especially the derivatives compound from eugenol. For examples allyl group transformation from eugenol to become aldehyde in vanillin used as additives in food, also hydroxyl transformation to alkyl, acyl or acetyl from eugenol like methyl eugenol, eugenyl benzoate and acetyl eugenol that can be used as bio-additive material in diesel fuel (Sastohamidjojo, 2004). The synthesis of 4-allyl-2-methoxy-6-amino phenol from eugenol nitration produces 4-allyl-2-methoxy-6-nitro phenol that is followed by reduction of nitro group to become amines. This compound is expected to have functions in medicine for pharmaceutical or for agricultural uses (Sudarma, et al, 2009). Similarly synthesis of amino methyl derivatives compound with anti-cancer activities from the reaction between eugenol with aniline from Mannich reaction (Rudianto, et al, 2014). Several amides and alkanolamides either aliphatic or aromatic derivatives are used widely as antibacterial, emulsifier, intermediates for synthesis of medicine like antibiotic (Dorge, 1982).

Based on the description above, the researcher is interested in synthesizing eugenol derivatives compound through etherification of hydroxyl group in eugenol from clove oil with $\alpha$ monochloroacetate to produce eugenyl acetate and followed by esterification reaction by methanol to produce methyl eugenol acetate. Next, through amidase using diethanolamide to produce 2-(4-allyl-2-methoxy phenoxy)-N,N-bis(2-hydroxyethyl) acetamide compound. 


\section{Materials and Methods}

Clove oil used was bought from chemical store in Medan for technical grade product. While the other materials, such as: diethanolamine, monochloroacetate acid, $\mathrm{NaOH}$ pellet, $\mathrm{Na}_{2} \mathrm{CO}_{3}$, diethyl ether, $\mathrm{HCl} 6 \mathrm{~N}$, saturated $\mathrm{NaCl}$, chloroform, methanol, silica gel $\mathrm{GF}_{254}, \mathrm{H}_{2} \mathrm{SO}$, $\mathrm{NaOCH}_{3}$, anhydrous $\mathrm{Na}_{2} \mathrm{SO}_{4}, \mathrm{n}$-hexane, benzene are practical grade (P.A.) by E. Merch.

\subsection{Eugenol Isolation from Clove Oil}

20.8 gram of solid $\mathrm{NaOH}$ was dissolved in $200 \mathrm{ml}$ aquadest in a $1 \mathrm{~L}$ beaker glass. Next, $100 \mathrm{ml}$ of clove oil was added gradually and stirred continuously with a magnetic stirrer. The mixture was poured into a separatory funnel and was extracted with n-hexane until two layers of solutions were formed. The lower layer (aqueous phase) was hydrolyzed after separation by adding $25 \% \mathrm{H}_{2} \mathrm{SO}_{4}$ until $\mathrm{pH}=3$ was reached. Then it was extracted with n-hexane solvent. The $\mathrm{n}$-hexane fraction was washed with water, dried by adding anhydrous $\mathrm{Na}_{2} \mathrm{SO}_{4}$ and filtered. The filtrate was evaporated using a rotary evaporator and eugenol was produced. Then the compound was purified using vacuum distillation. Finally, the distillate produced was analyzed using gas chromatography and FT-IR spectroscopy.

\subsection{The Synthesis of Eugenyl Acetate}

88 gram $(0.041 \mathrm{~mol})$ of eugenol was put into $250 \mathrm{ml}$ Erlenmeyer flask. Then, $14 \mathrm{ml}$ of aquadest and 6 gram $(0.15 \mathrm{~mol})$ of solid $\mathrm{NaOH}$ were added. The mixture was homogenized by stirring. Next, 6 gram (0.063 mol) of monochloroacetate acid was added, with a continuous stirring, the mixture is heated in a boiling water bath until a solidified mixture was formed. The solid produced was chilled and acidified using $\mathrm{HCl} 6 \mathrm{~N}$ until $\mathrm{pH} \leq 4$ was reached. After that, it was extracted with $100 \mathrm{ml}$ of ether, the ether layer was washed with $30 \mathrm{ml}$ of aquadest and extracted with 4 gram of $\mathrm{Na}_{2} \mathrm{CO}_{3}$ dissolved in $30 \mathrm{ml}$ of aquadest. $\mathrm{HCl} 6 \mathrm{~N}$ was added into carbonate solution until $\mathrm{pH}=2$, and the mixture was chilled, filtered, dried and was recrystallized using hot water. The solid obtained was put to dry in an oven at $50^{\circ} \mathrm{C}$. Finally, eugenyl acetate was obtained and it was weighed and analyzed using FT-IR spectroscopy.

\subsection{The Synthesis of Methyl Eugenol Acetate}

5 gram $(0.024 \mathrm{~mol})$ of eugenyl acetate, $10 \mathrm{ml}$ of methanol absolute and $20 \mathrm{ml}$ of benzene were put into a $250 \mathrm{ml}$ of three neck flash and stirred with a magnetic stirrer. A set of reflux equipment was assembled and $2 \mathrm{ml}$ of $\mathrm{H}_{2} \mathrm{SO}_{4}$ (c) was added and stirred at cold state. The mixture was refluxed for 5 hours, then, excess benzene and methanol were evaporated using a rotary evaporator. The precipitate was dissolved into $25 \mathrm{ml}$ of $\mathrm{n}$-hexane and washed twice with $5 \mathrm{ml}$ of aquadest. The n-hexane layer was dried using anhydrous $\mathrm{Na}_{2} \mathrm{SO}_{4}$ and filtered. The solvent in the 
filtrate was evaporated using a rotary evaporator. Methyl eugenol acetate produced was weighed and analyzed using an FT-IR spectrophotometer.

2.4. The Synthesis of 2-(4-Allyl-2-Methoxy Phenoxy)-N,N-Bis(2-Hydroxyethyl) Acetamide.

4 gram $(0.018 \mathrm{~mol})$ of methyl eugenol acetate was added into a $250 \mathrm{ml}$ three neck flask, $2 \mathrm{ml}$ $(0.020 \mathrm{~mol})$ of diethanolamine was added and stirred. A set of reflux equipment was assembled and 2 gram of $\mathrm{CH}_{3} \mathrm{Ona}$ in $10 \mathrm{ml}$ of methanol was added. The mixture was refluxed with continuous stirring for 5 hours. Then, the product was evaporated in a rotary evaporator. The precipitate obtained was extracted with $50 \mathrm{ml}$ of diethyl ether and washed by $5 \mathrm{ml}$ of saturated $\mathrm{NaCl}$ for 3 times. The upper layer of the mixture was added with anhydrous $\mathrm{CaCl}_{2}$ and filtered. The filtrate was dried with anhydrous $\mathrm{Na}_{2} \mathrm{SO}_{4}$ and filtered. The solvent in the filtrate was evaporated using a rotary evaporator. Next, the precipitate obtained, 2-(4-allyl-2-metxy phenoxy)-N,N-bis(2-hydroxyethyl) acetamide, was weighed and analyzed using TLC and followed by analysis using FT-IR and ${ }^{1} \mathrm{H}-\mathrm{NMR}$ spectrophotometer.

\section{Results And Discussion}

\subsection{Eugenol Isolation from Clove Oil}

The isolation of eugenol from clove oil has produced $71 \%$ of yield with $97.70 \%$ purity based on gas-liquid chromatography analysis. The separation of eugenol from the oil was done by the formation of Na-eugenolate salt with the addition of $\mathrm{NaOH}$ to eugenol which aims for solubility in polar solvent and the compound can be separated from other non-polar components in clove oil except eugenol. Na-eugenolate was then hydrolyzed to release eugenol by using $25 \% \mathrm{H}_{2} \mathrm{SO}_{4}$ untuk $\mathrm{pH}=3$ was reached. Eugenol can be separated from the liquid phase by using $\mathrm{n}$-hexane in the extraction process. The physical properties for purified eugenol in vacuum distillation at $111^{\circ} \mathrm{C}$ and $5 \mathrm{mmHg}$ pressure involves density at $1.0634 \mathrm{~g} / \mathrm{ml}$, reflective index of 1.5364 with clove aroma and yellowish color liquid. The reactions occurred during the isolation process were salt formation and followed by hydrolysis with $\mathrm{H}_{2} \mathrm{SO}_{4}$ (Figure 1). FT-IR spectroscopy spectrum of eugenol gave peaks at wavelengths (v) of $3512 \mathrm{~cm}-1$ that shows -OH group, 3010 cm-1 that gives C-H sp2 in allyl and aromatic ring, $2976 \mathrm{~cm}-1$ for C-H sp3 in methoxy group. Then, $\mathrm{v}=1641 \mathrm{~cm}-1$ shows $\mathrm{C}=\mathrm{C}$ bonds in central benzene and allyl group. Furthermore, absorbance band in $\mathrm{v}=1300-1100 \mathrm{~cm}-1$ is a stretching vibration of $\mathrm{C}-\mathrm{O}-\mathrm{C}$ which is a methoxy with central benzene core (Figure 2). 
<smiles>C=CCc1ccc(O)c(OC)c1</smiles>

Eugenol

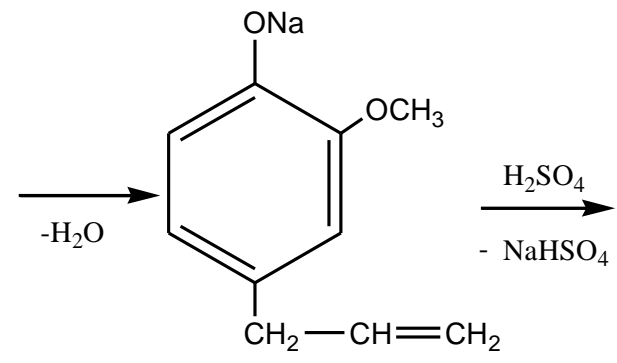

Natrium Eugenolat<smiles>C=CCc1ccc(O)c(OC)c1</smiles>

Eugenol

Figure 1. Isolation reaction of eugenol from clove oil

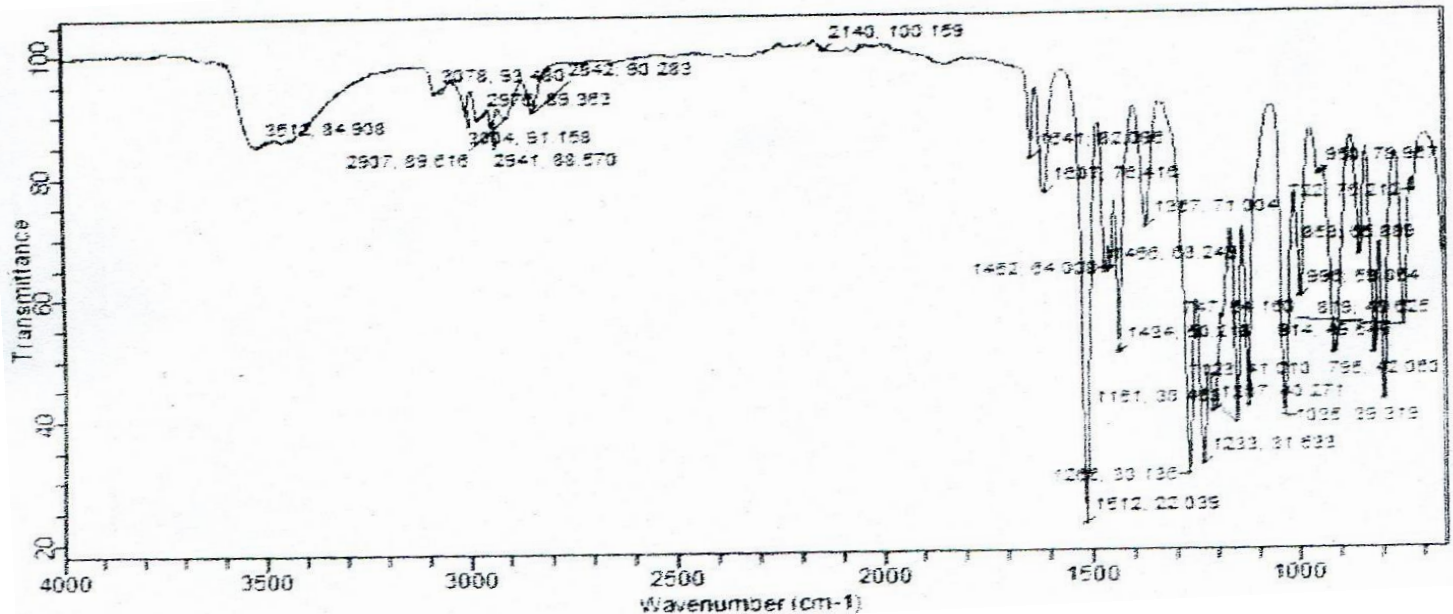

Figure 2. FT-IR spectrum of eugenol isolated from clove oil

\subsection{The Synthesis of Eugenyl Acetate}

From 6.88 gram, $(0.041 \mathrm{~mol})$ of eugenol used in the study, 6.02 gram $(70.52 \%)$ of eugenyl acetate was formed in white solid form. The reaction for eugenyl acetate synthesis started by the improvement of nucleophilicity from element $\mathrm{O}$ in -OH groups from eugenol to become -Ona in Na-eugenoxide that followed by nucleophilic substitution reaction with $\alpha$-monochloroacetate that produces eugenyl acetate (Figure 5). FT-IR spectroscopy spectrum analysis for eugenyl acetate gave expanded peaks at wave number $(\mathrm{v})=3425 \mathrm{~cm}^{-1}$ that showed $-\mathrm{OH}$ vibration from $\mathrm{COOH}$ group of eugenyl acetate. Then the appearance of vibration peak at $1751 \mathrm{~cm}^{-1}$ showed $\mathrm{C}=\mathrm{O}$ vibration in $\mathrm{COOH}$ group (Figure 3). 


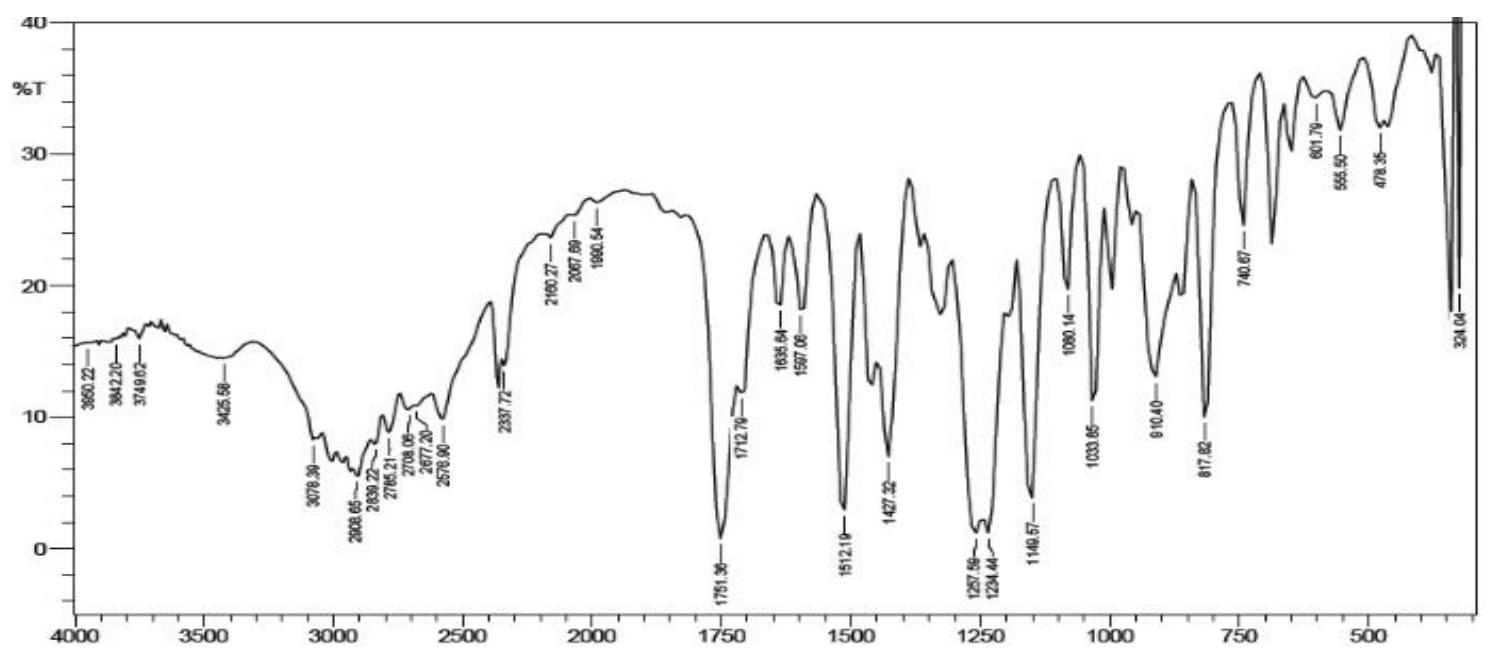

Figure 3. FT-IR spectrum of Eugenyl Acetate

\subsection{The Synthesis of Methyl Eugenol Acetate}

From 5 gram $(0.024 \mathrm{~mol})$ of eugenyl acetate used, 4.335 gram $(81.362 \%)$ of methyl eugenol acetate in clear yellowish liquid was formed. In this step, methyl eugenol acetate was an intermediate to synthesis amide compound in a low temperature as it is easier to form amide compounds derives from methyl esther than a direct amidase to carboxylate group (Figure 5). FT-IR spectrum of methyl eugenol acetate supports that the compound produced showed a disappearance of $-\mathrm{OH}$ group vibration at $\mathrm{v}=3425.58 \mathrm{~cm}-1$ when in compare to eugenyl acetate spectrum. Moreover, there were changes of vibrational peaks for $\mathrm{C}=\mathrm{O}$ group at $\mathrm{v}=1751.36 \mathrm{~cm}^{-1}$ in eugenyl acetate to $1767.53 \mathrm{~cm}^{-1}$. This is dues to the substitution of the functional group attached to $\mathrm{C}=\mathrm{O}$ to $\mathrm{OCH}_{3}$ from $\mathrm{OH}$. The energy needed to vibrate $\mathrm{C}=\mathrm{O}$ group from $\mathrm{CooCH}_{3}$ is bigger than that in $\mathrm{COOH}$ therefore the wave number in $\mathrm{C}=\mathrm{O}$ from $\mathrm{COOCH}_{3}$ is bigger (Figure 4).

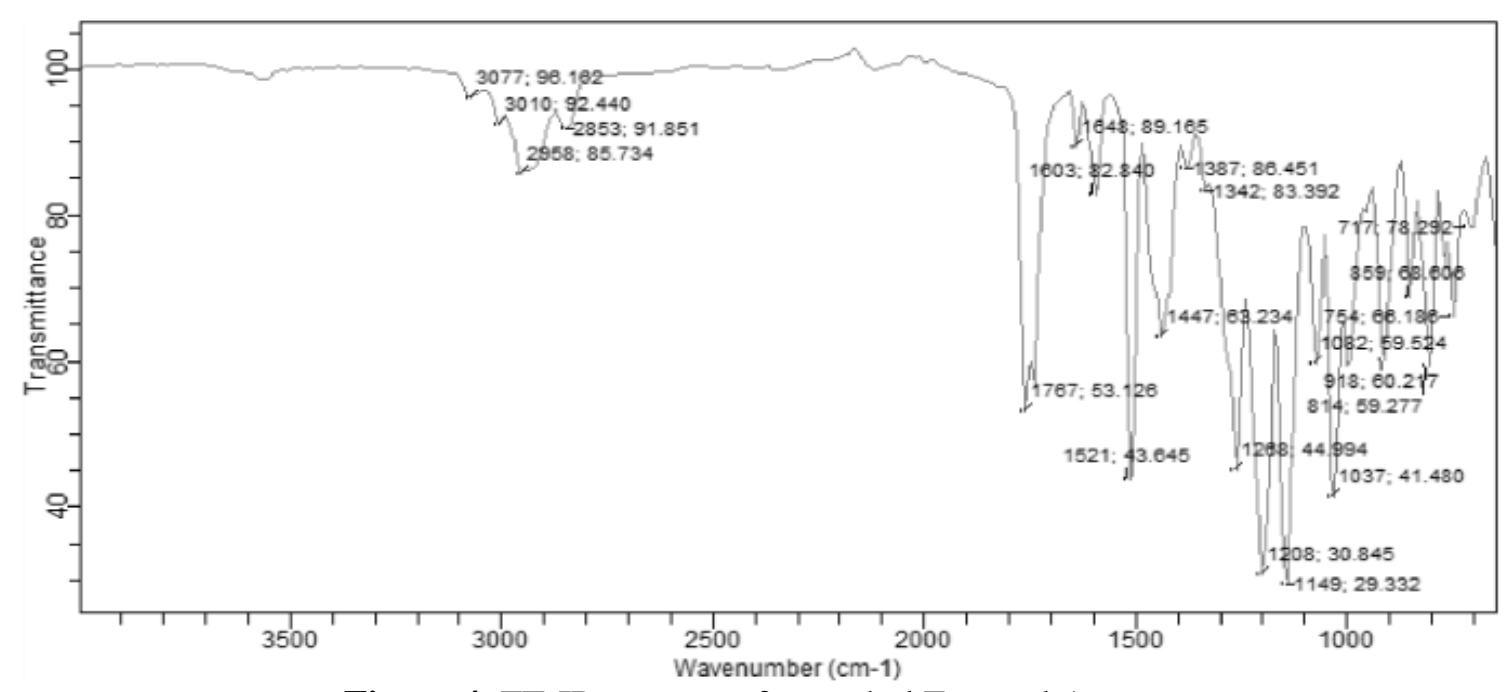

Figure 4. FT-IR spectrum for methyl Eugenol Acetate 


\subsection{The Synthesis of 2-(4-Allyl-2-Methoxy Phenoxy)-N,N-Bis(2-Hydroxyethyl) Acetamide}

From 4 gram of methyl eugenol acetate used, 3.876 gram (72.99\%) of 2-(4-allyl-2-metxy phenoxy)-N,N-bis(2-hydroxyethyl) acetamide compound was formed which is a yellow solid. In amide reaction, the carboxylic group from eugenyl acetate was transformed to methyl ester. Therefore, amination was easier in order to produce amide compounds such as 2-(4-allyl-2metxy phenoxy)-N,N-bis(2-hydroxyethyl) acetamide compound (Figure 5). The amidase of carboxylate group normally takes place at high temperature with decarboxylation occur. FT-IR spectroscopy analysis of the compound synthesized showed the disappearance of $\mathrm{C}=\mathrm{O}$ vibration group from ester at $1752.38 \mathrm{~cm}^{-1}$ wavelength to $1591.91 \mathrm{~cm}^{-1}$ in amide and supported by the reappearance of $3487.30 \mathrm{~cm}^{-1}$ wavelength which show the vibration of $-\mathrm{OH}$ group from ethanolamine (Figure 6).

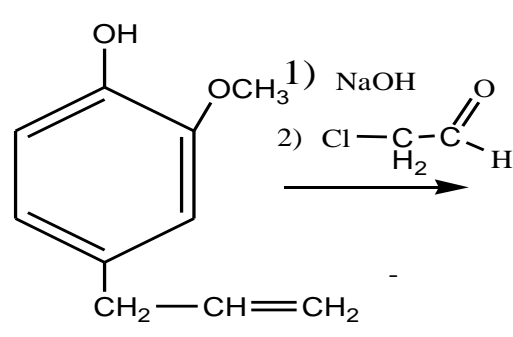

Eugenol

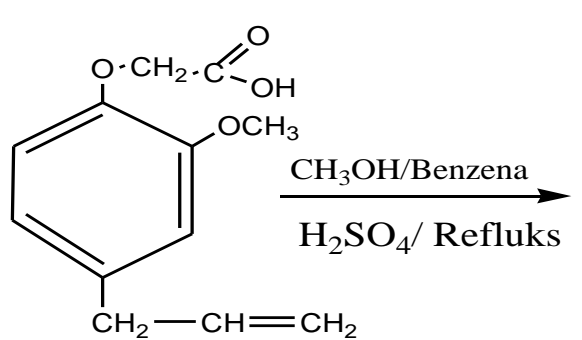

Asam Eugenoksi asetat

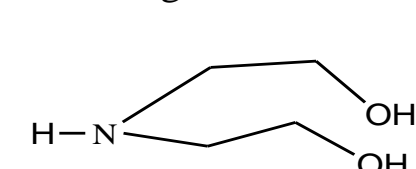

Dietanol amina<smiles>C=CCc1ccc(OCC(=O)OC)c(OC)c1</smiles>

Metil Eugenoksi asetat

\section{$\mathrm{CH}_{3} \mathrm{ONa} / \mathrm{CH}_{3} \mathrm{OH}$}

Refluks

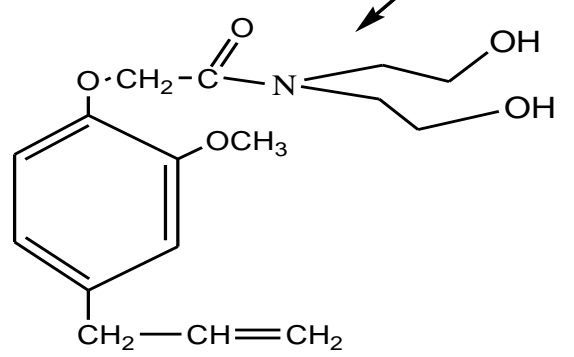

2-(4-alil-2-metoksifenoksi)-N,N-bis (2-hidroksietil)asetamida

Figure 5. The synthesis reaction of 2-(4-allyl-2-metxy phenoxy)-N,N-bis(2-hydroxyethyl) acetamide compound from eugenol

${ }^{1}$ HNMR spectroscopy analysis of 2-(4-allyl-2-metxy phenoxy)-N,N-bis(2-hydroxyethyl) acetamide compound (Figure 7) showed 8 protons environments with chemical shifting $(\delta)$ of : (1) $\delta=2.7 \mathrm{ppm}$ (t) for 4 protons $-\mathrm{CH}_{2}-\mathrm{N}$, (2) $\delta=3.6 \mathrm{ppm}$ (t) for 4 protons $-\mathrm{CH}_{2}-\mathrm{OH}$, (3) $\delta=3.8$ ppm (s) for 3 protons $-\mathrm{O}-\mathrm{CH}_{3}$, (4) $\delta \mathrm{c}=4.3 \mathrm{ppm}(\mathrm{s})$ for 2 protons $-\mathrm{CH}=\mathrm{O},(5) \delta=4.8 \mathrm{ppm}(\mathrm{s})$ for 2 protons $-\mathrm{OH},(6) \delta=5.0 \mathrm{ppm}(\mathrm{m})$ for 2 protons of allyl (-CH2-), (7) $\delta=5.9 \mathrm{ppm}(\mathrm{m})$ for 1 proton of allyl $(-\mathrm{C}=\mathrm{CH}-)$ and $\delta=6.8 \mathrm{ppm}(\mathrm{m})$ for 3 protons of unsubstituted central benzene 
core. The chemical shifting of allyl groups were multiplet as protons were coupling in allyl groups and therefore they form multiple signals. Similarly, this happened to protons in element $\mathrm{C}$ that attached to central benzene.

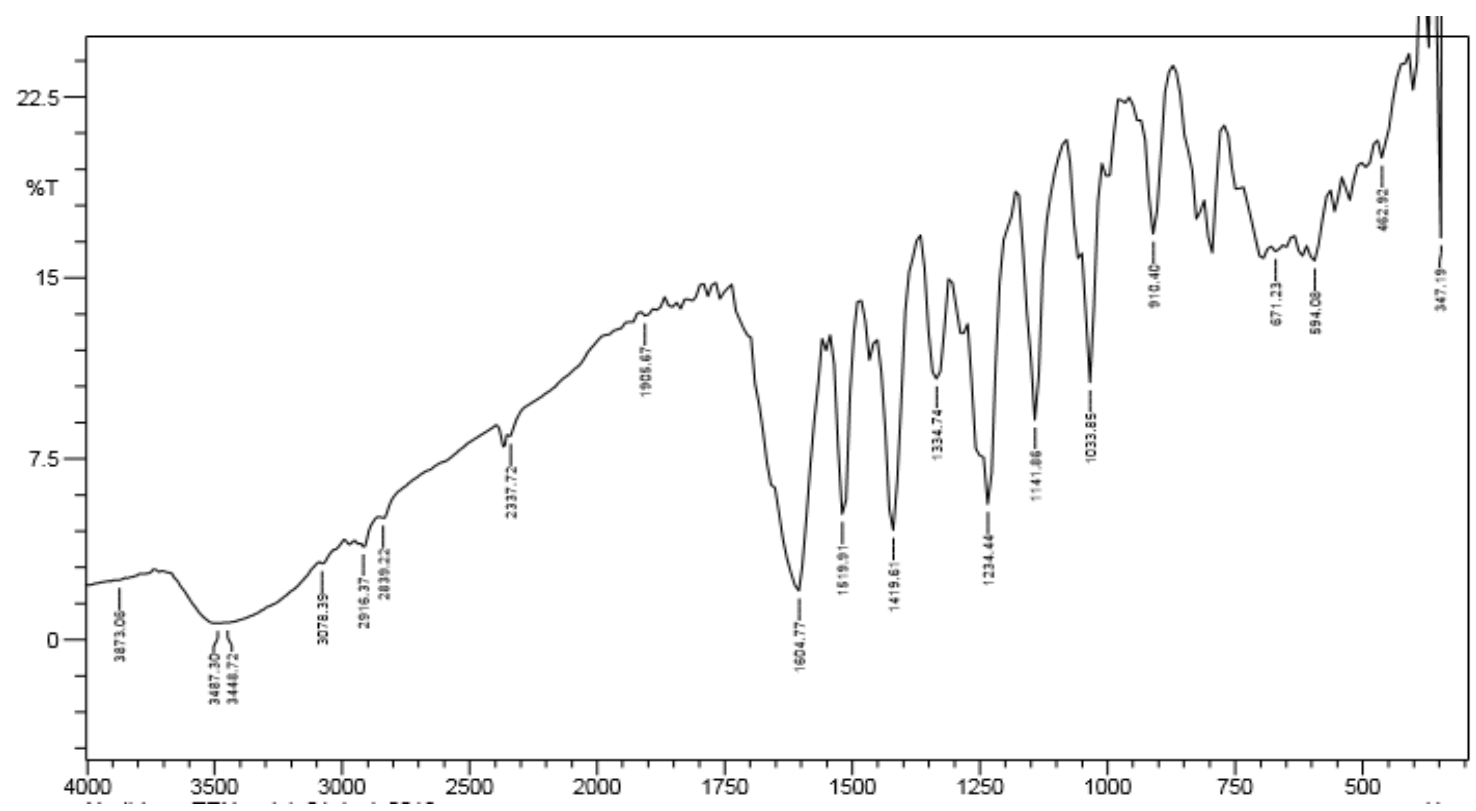

Figure 6. FT-IR spectrum for 2-(4-allyl-2-metxy phenoxy)-N,N-bis(2-hydroxyethyl) acetamide

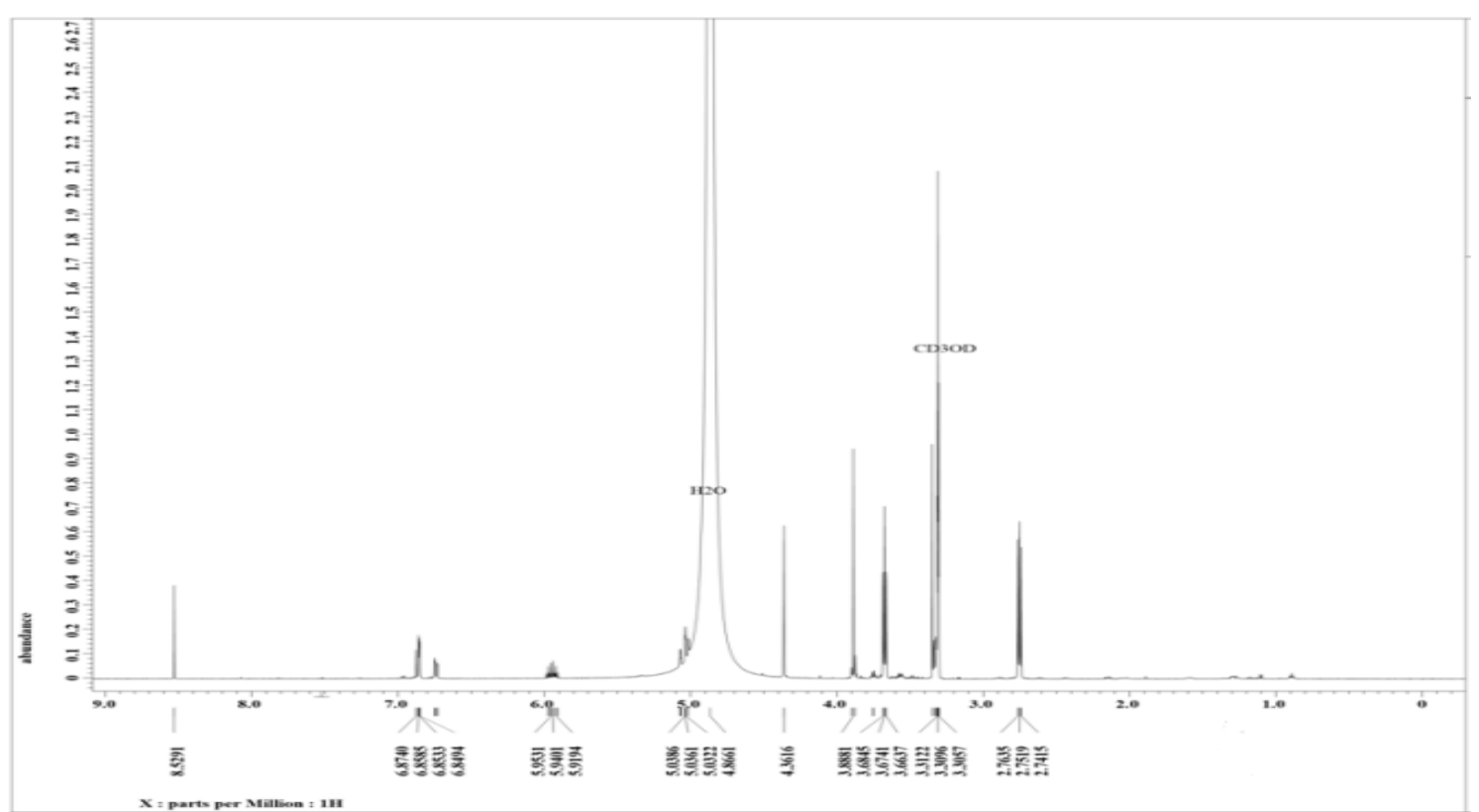

Figure 7. ${ }^{1}$ HNMR spectrum for 2-(4-allyl-2-metxy phenoxy)-N,N-bis(2-hydroxyethyl) acetamide 


\section{Conclusion}

$71 \%$ of eugenol can be isolated from clove oil and 2-(4-allyl-2-metxy phenoxy)-N,N-bis(2hydroxyethyl) acetamide compound can be synthesized from eugenol with 3 steps, such as alkoxylation, esterification and amidase. This can be concluded that:

1. The synthesis of eugenyl acetate from alkoxylation of eugenol in $\mathrm{NaOH}$ solution and with Williamson etherification reaction with $\alpha$-monochloroacetate has given $70.52 \%$ yield.

2. Methyl eugenol acetate synthesized through the esterification of eugenyl acetate with methanol in benzene and $\mathrm{H}_{2} \mathrm{SO}_{4}$ (c) catalyst in reflux condition has produced $81.36 \%$ of yield.

3. Amidase of methyl eugenol acetate was done to produce 2-(4-allyl-2-metxy phenoxy)-N,Nbis(2-hydroxyethyl) acetamide compound with diethanolamine in methanol with $\mathrm{NaOCH}_{3}$ catalyst and has yielded $72.99 \%$ of the compound.

\section{References}

Alma, M.H., Ertas, M, Nitz,S., and Kollmannsberger,H.,2007, Chemical Composition and content of essential oil from the bud of cultivated Turkish clove (Szygium aromaticum L), Bio Resources.

Anwar, C, 1994, The Convertion of Eugenol Into More Valuable Substances Docyoral Decertation, Yokyakarta Gajah Mada University.

Dorge, R.F., 1982, Buku Teks Wilson dan Gisvold Kimia Farmasi dan Medisinal Organik, Bagian I, Edisi VIII, terjemahan A.M. Fatah, Penerbit IKIP Semarang.

Kardiman, A, 2005, Tanaman Penghasil Minyak Atsiri, Jakarta, Agromedia Pustaka.

Pramod, K., Ansari, S.H. and Ali, J.2010. Eugenol a natural compound withversatilepharmacological actions. Natural Product Communications .

Rudyanto, M., Ekowati, J., Widiandani, T., Honda, T., 2014, Synthesis and brine shrimp lethality test of some benzoxazine and aminomethyl derivatives of eugenol Internasional Jornal of Pharmacy and Phamaceutical Sciences. 6 (2): 46546728

Satrohamidjojo, H.2004. Kimia Minyak Atsiri. Yogyakarta. UGM.

Silverstein, R.M. 1986. Penyelidikan Spektroskopi Senyawa Organik. Edisi eempat. Jakarta. Erlangga

Sudarma,M,I, Ulfa, M and Suhono, 2009, Synthesis of 4-Alil-2-Metoxy-6-Aminophenol from Natural Eugenol, Indo, J, Chem, 9(1), 84-88.

Vianney, M.B. 2011. Sintesis Derivat 6- dietilaminometil dan 6-bis-(2-hidroksietil) aminometil

Dari Eugenol dengan Reaksi Mannich. [Tesis]. FakultasMIPA. Surabaya.

Wiratno.2009. Cengkih berpotensi sebagai pestisida nabati. Warta Penelitian dan Pengembangan Pertanian. 